Tér és Társadalom 20. évf. 2006/2. 103-113. p.

Tér és Társadalom

$X X$. évf. $2006 \square$ 2: 103-141

GYORS TÉNYKÉP

\title{
A JOGI SZABÁLYOZÁS SZEREPE A KöZÖSSÉGI FORRÁSOK FELHASZNÁLÁSÁBAN
}

\author{
(Role of Regal Regulation in using of Public Funds)
}

\author{
FINTA ISTVÁN
}

Kulcsszavak:

közösségiforrások strukturális alapok regionális politika alapelvek pályázati rendszer

A terület-és gazdaságfejlesztési célok megvalósítása során meglehetősen nagy szerepet kapnak a közösségi és nemzeti támogatások, melyek elérhetõsége - túlnyomó többségben - pályázatok formájában biztositott. Eppen ezért küilönösen fontos a pályázatok kialakitása, illetóleg a pályázatokra vonatkozó jogi szabályozás léte, minôsége és részletezettsége, melyek együttesen meghatározó befolyást gyakorolhatnak a különbözō földrajzi területi egységek versenyképességére.

A pályázati források közpénzek elosztásának, továbbá az állami irányitás, a társadalmi, gazdasági életbe történö beavatkozás egyik - rendkívül fontos - formáját képviselik, ezért jogállamban nem keriulhetö meg a pályázatokra vonatkozó megfelelő szintủ és tartalmú jogi szabályozás kialakítása.

A tanulmány bemutatja a strukturális alapok elveinek érvényesülését, illetöleg az érvényesülés problémáit és korlátait a vonatkozó jogi szabályozásban. Ezt követỏen a pályáztatás eljárási kérdései gyakorlati és szabályozási tapasztalatait vázolja.

\section{Bevezetés}

A gazdaság fejlődését előmozdító tényezỏk között alapvető szerepet játszanak a reálfolyamatok belsó törvényszerüségei szerint zajló folyamatok, illetỏleg az állami szerepvállalás, amely különbơzỏ gazdaságpolitikákból táplálkozva (monetáris, fiskális stb.) kívánja a gazdaság fejlödését az egyéb állami érdekek figyelembe vétele mellett elősegíteni.

Az egyes gazdaságpolitikák, illetve az ezekbỏl építkezỏ egyes kormányzati programok közvetlenül nem jelennek meg a jogalkotásban, az egyes jogszabályokban. Mindamellett az egyes fejlesztési célok eléréséhez nélkülözhetetlen a jogi szabályozás, mint irányítási, feltételteremtő és korlátokat megállapító eszköz. A cél-eszkő̉z viszony egyúttal azt is jelzi, hogy a gazdaságfejlesztésben elsỏdleges szerep és felelösség az alkalmazott gazdaságpolitikára, illetve annak megalkotóira hárul, a jogszabályok jelentősége ebbỏl a szempontból „csupán” másodlagosnak tekinthető. Ugyanakkor a jogszabályok segítségével határozzák meg azokat a kompetenciákat, a döntési jogosítványok területi szinteket érintő tartalmát, amelyek megszabják a kủlönbözỏ területi szintủ szervezetek gazdaságfejlesztési feladatait, lehetőségeit. 
Finta István: A jogi szabályozás szerepe a közösségi források felhasználásában.

Tér és Társadalom, 20. 2006. 2. 103-113. p.

A terület- és gazdaságfejlesztési célok megvalósítása során meglehetősen nagy szerepet kapnak a közösségi és nemzeti támogatások, melyek elérhetósége - túlnyomó többségben - pályázatok formájában biztosított. Éppen ezért különösen fontos a pályázatok kialakítása, illetỏleg a pályázatokra vonatkozó jogi szabályozás léte, minỏsége és részletezettsége, melyek együttesen meghatározó befolyást gyakorolhatnak a különböző földrajzi területi egységek versenyképességére.

A közösségi és a hazai területfejlesztési célok megvalósítását szolgáló intézményés eszközrendszer müködése Magyarországon ez ideig korántsem tekinthető problémamentesnek. Az alábbiakban azokra a jelentösebbnek tekinthető gondokra kívánjuk felhívni a figyelmet, amelyek orvoslása hozzájárulhat a rendszer továbbfejlesztéséhez, az eredményes és zavartalan mủködtetés biztosításához. A vizsgálat során különös figyelmet szenteltuink a jogi szabályozásnak, a közösségi alapelvek érvényesülésének és a gyakorlati tapasztalatok alapján levonható következtetéseknek.

\section{A pályázatok jelentősége jogi szabályozási szempontból}

A pályázatok különösen fontos szerepet játszanak a Strukturális Alapok céljainak megvalósításában, hiszen egyrészt ez a támogatások biztosításának egyik legfontosabb formája, másrészt a pályázatok tartalma és követelményrendszere alapján mérhetö, hogy a tervezés során meghatározott célok, valamint alapelvek gyakorlati megvalósítására mutatkozik-e igény, vagy a pályázatok ad-hoc jellegủ nem a programok, programozási tevékenységre építő célok megvalósítását szolgálják. A tervezés és célmegvalósítás kiinduló pontja a tagállam, illetve a közösség által elfogadott tervdokumentum (NFT, KTK, NSRK), amelyben a célkitüzések meglehetősen általános megfogalmazásban szerepelnek. A dokumentumokban meghatározott célok megvalósulása elött az utolsó, illetve utolsó elötti pontot az általános célok konkretizálását jelentô programok vagy projektek képezik, amelyek alakulására a pályázati kiírás döntő befolyást gyakorol. Ez egyúttal azt is jelenti, hogy a pályázati kiŕrás, majd pedig a - jó esetben a kiírás alapján születỏ - döntés egyuittesen képes bemutatni, hogy az általános célok és a közösségi alapelvek a gyakorlatban miként valósulhatnak meg.

A pályázati források közpénzek elosztásának, továbbá az állami irányítás, a társadalmi, gazdasági életbe történỏ beavatkozás egyik - rendkívül fontos - formáját képviselik, ezért jogállamban nem kerülhetỏ meg a pályázatokra vonatkozó megfelelő szintủ és tartalmú jogi szabályozás kialakítása.

Elsỏként az elvekre - ha úgy tetszik potenciális, vagy tényleges anyagi jogi normákra - vonatkozó megállapítások bemutatására kerül sor, majd pedig a pályáztatás eljárási kérdéseiről esik szó.

\section{A koncentráció elve}

Első kérdésként az fogalmazható meg, hogy a pályázatok milyen módon járulnak hozzá a térségi hatású programok megvalósításához, a területi kapcsolatok kialakításához, erősítéséhez, végső soron a fölrajzi koncentráció érvényesüléséhez. A 
Finta István: A jogi szabályozás szerepe a közösségi források felhasználásában.

Tér és Társadalom, 20. 2006. 2. 103-113. p.

TÉT XX. évf. 2006 - 2

Gyors ténykép

105

válasz kialakítása elött szükséges tisztázni, milyen módon jöhet létre térségi program vagy projekt. Ennek egyik módja, az egyetlen földrajzi ponton megvalósuló, ám egy egész térségre (kistérség, megye, régió) hatást gyakorló program, projekt (pl.: regionális hulladékfeldolgozó, felsőoktatási, egészségügyi ellátó centrum, stb.). A másik lehetséges mód az azonos célok alapján különböző, de földrajzilag összefüggő területi egységek szereplőinek (pl.: települési önkormányzatok) együttműködése során kialakuló térségi program, projekt. Vélhetően az első módon létrejött, illetve a jövőben létesülö programok száma csekélyebb (regionális repülötér, regionális hulladékfeldolgozó, felsőoktatási-, egészségügyi ellátó centrum stb.), míg az alsóbb szintủ együttmúködésen alapuló térségi programok száma jelentősebb, különös tekintettel az eddigi egyủttmüködési lehetőségek kiaknázatlanságára.

Kérdés tehát, hogy a pályázatok milyen módon segítik elő a térségi programok megvalósítását. Erre az a válasz adható, hogy leginkább sehogy. A pályázatok egyrészt követelményként fogalmazhatnák meg a térségi hatás igazolását (egyiket a fenti két megoldás közül), melynek hiánya egyúttal a támogathatóság hiányát is jelentené, másrészt az értékelés során elönyben részesíthetnék a térségi hatású programokat. Ez ideig sem az uniós, sem a hazai pályázatok nem tartalmaznak ilyen szabályokat.

Ez alól nagyon szük körre alkalmazható - hazai forrásokra vonatkozó - kivételt jelent a decentralizált helyi önkormányzati fejlesztési támogatási programok előirányzatai, valamint a vis maior tartalék felhasználásának részletes szabályairól szóló 27/2005. (II. 14.) kormányrendelet, mely egyedül a települési hulladék kezelés fejlesztése tekintetében részesíti elönyben a térségi szemléletmódot és a több önkormányzat összefogásával megvalósítandó beruházásokat (14. § (8) bek.). ( $\mathrm{E}$ területen nem csupán az előnyben részesítés, hanem a támogathatóság alapját kizárólag a térségi együttmüködés képezhetné.)

\section{Programozás, programfinanszírozás}

Sem a hazai, sem pedig az uniós pályázatok nem követelik meg azt, hogy a támogatandó tevékenységek részét képezzék az adott területi szinten elfogadott területfejlesztési programnak. A pályázati kiŕrások gyakran tartalmaznak olyan elöírást, mely szerint az adott területfejlesztési tanácsnak igazolnia kell a benyújtandó pályázat fejlesztési programhoz történő illeszkedését. Ennek a pályázói, illetve pályázati igénynek a tanácsok formailag szinte kivétel nélkủl eleget tesznek. A jelenlegi források ez ideig nem tették lehetővé, hogy a területfejlesztés különbözö szereplöi közép-, esetleg hosszú távú programjaikat megvalósíthassák. A hazai területfejlesztés eszközrendszere nem programfinanszírozást, hanem a helyi, területi programokhoz nem feltétlenül kapcsolódó, nagyobb részt központilag meghatározott projektek támogatását helyezte elötérbe. A különböző területi szintü szervezetek által elkészített fejlesztési programok súlya, jelentősége ezáltal meglehetősen csekélynek minősíthetô. Ez a helyzet mindaddig nem fog megváltozni, amíg a pályázati kiírások nem az alulról felfelé építkezö területi programok megvalósulását támogatják, vagy legalább megkövetelik azt, hogy az adott célkitủzés a területi program része legyen 
(nem csupán illeszkedésröl lehet szó). Ehhez természetesen az is szükséges, hogy a támogatandó célokat a pályázat kiírója csak átfogó módon határozza meg, helyet adva a helyi-területi igények szerinti konkrét célkitüzések megfogalmazásának és megvalósításának. (Ez a követelmény független attól, hogy a pályázatokat központi, vagy regionális szinten alakítják-e ki.) A pályázat kiúrására jogosult szerv - e logika szerint - a fejlesztések irányát oly módon befolyásolhatja, hogy (részletes célmeghatározás helyett) negatív taxációval azokat a tevékenységeket sorolná fel, melyek támogatását nem tartja kívánatosnak. (A pályázati szabályok jelzett módon történő alakítása összhangban állna azzal a közösségi filozófiával, mely a felsöbb szintü és a területi igények, lehetöségek tekintetében talán kevéssé kompetens - döntéshozó szervek jogosítványait a stratégiai irányításra korlátozza. E filozófiának köszönhetöen változtak a közösségi célok, prioritások és tünnek el a programkiegészítő dokumentumok a következő programozási idószakra vonatkozó szabályozás szerint.)

A hazai forrásokkal kiegészített uniós pénzeszközök nagyságrendje lehetőséget biztosíthat arra, hogy a különálló, jórészt területi hatással nem rendelkező településfejlesztési projektek helyett, vagy mellett végre sor kerüljön a több éves területi szintủ programok megvalósítására is. Ez a cél természetesen csak az ennek megfelelö pályázati kiírások mellet valósulhat meg.

Általános tapasztalat, hogy - különösen az uniós források felett rendelkezni jogosult - irányító hatóságok rendkívüli módon idegenkednek a sokszereplős térségi programoktól, sokkal inkább előnybe részesítik az egy szereplös és nem feltétlen térségi hatású, de emellett rendkívül költségigényes projekteket. Ez egyúttal azt is jelenti, hogy a pénzügyi koncentráció tiszteletben tartása és érvényesítése mellett (a minimális támogatható projektnagyság) a földrajzi koncentráció (mely alapvetỏen a legrászorultabb területek támogatását jelenti ${ }^{1}$ ) csak részlegesen vagy egyáltalán nem érvényesül ${ }^{2}$.

\section{Partnerség}

A fenti megállapítás egy további problémát is jelez, mégpedig a partnerség érvényesülésének hiányát a hazai pályázati rendszeren belül. A pályázatok jelentős része egyáltalán nem követeli meg a partneri kapcsolatok fennállását vagy jövöbeni kialakítását, illetőleg csekély mértékben értékeli azokat. A területi értelemben vett partnerség fontosságának felismerése - annak követelményként történő rögzítése és értékelése - pedig mindezideig elkerülte a pályázat kiírók figyelmét.

Teljesen önálló értékelési szempontként a partnerség a 2004. évi SAPARD pályázaton belül ${ }^{3}$ jelent meg, ahol a partneri együttmüködést számos szempont szerint értékelték. Ez az önmagában pozitív tény sajnos nem jelentette azt, hogy a térségi partnerségnek, összefogásnak bármiféle jelentöséget tulajdonítottak volna. A nyertes pályázatok alapján érzékelhető, hogy kizárólag települési projekteket támogattak, térségi összefogáson alapuló programok nem szerepelnek a nyertesek listáján. 
Finta István: A jogi szabályozás szerepe a közösségi források felhasználásában.

Tér és Társadalom, 20. 2006. 2. 103-113. p.

TÉT XX. évf. 2006 - 2

Gyors ténykép

107

A SAPARD programot követỏ AVOP pályázati felhívás már nem foglakozott érdemben a partneri kapcsolatokkal, csakúgy, mint általában a Strukturális Alapok forrásaira vonatkozó egyéb pályázatok.

\section{A pályázati kiírásokra vonatkozó egyéb észrevételek}

- A pályázatok jelentős részének címzettjei (a pályázók köre) nonprofit szervezetek, illetöleg önkormányzatok. Ugyanakkor a pályázati felhívásokat sok esetben oly módon fogalmazzák meg, mintha azok a profit szféra szereplőire vonatkoznának. Ez a gyakorlatban olyan dokumentumok igénylését jelenti, amellyel a profit szféra szereplöi rendelkeznek, az önkormányzatok számára viszont azok nem kötelezőek (pl.: közjegyző által hitelesített aláíási címpéldány.). Mindez csupán azt kívánja érzékeltetni, hogy egyetlen apró pályázati rendelkezés - amely nem illeszkedik a potenciális címzettek viszonyaihoz - teljesen ellehetetlenítheti az amúgy kiváló célok, kezdeményezések megvalósítását is.

- Rendkívül szoros és jogvesztő határidök az egyik oldalon, és a határidök be nem tartása - szankciók nélkül - a másik oldalon. A komoly, sokszereplös és nagy beruházás igényŭ programok előkészítése meglehetősen hosszú folyamat, amelyet jelentősen befolyásol más államigazgatási szervek engedélyezési, ügyintézési határidejének terjedelme, kapacitása is. Ha a meghirdetés és a beadási határidỏ közötti időszak nagyon rövid, akkor a jelentősebb programok elkészítésének lehetősége csekély, illetőleg minőségük nem éri el a megkívánt szintet. Így a jelentősebb és a területi folyamatokra érdemi hatást gyakorló programok hátrányba kerülhetnek a kevésbé fontos célokat tartalmazó, de egyszerúbb helyi projektekhez képest. Ez a probléma különösen a folyamatos beadású pályázatok esetén válhat jelentőssé a rendelkezésre álló keret gyors kimerítésének veszélye miatt.

- A pályázatok megfogalmazása gyakran nem kellően egyértelmủ, többféle értelmezésre ad lehetőséget, illetőleg túlságosan általános. Ez az állapot lehetőséget nyújt az értékeló számára, hogy a kiŕrást saját szempontjai, esetleg más érdekei szerint értelmezze, illetve újraértelmezze. Olyan esetre is volt példa, hogy egy több projektből álló program egyes elemeire az értékelő úgy nyilatkozott, hogy azok nem tartoznak a támogatható tevékenységek közé, viszont az adott projektek céljai és tevékenységei nem szerepeltek azon a listán, amelyen a nem támogatható tevékenységeket felsorolták. A pályázati kiírás meghirdetés utáni módosítására ugyan nincs mód, de újraértelmezésére - a tapasztalatok szerint - mégis lehetőség nyílik. Elvileg az értelmezési problémák egyértelmủsítését szolgálják a gyakran ismételt kérdésekre adott válaszok. Ez a típusú segítség gyakran hasznos, sokszor azonban nem kerül sor a kérdés tényleges tisztázására. 
Finta István: A jogi szabályozás szerepe a közösségi források felhasználásában.

Tér és Társadalom, 20. 2006. 2. 103-113. p.

\section{Az eljárási szabályok értékelése}

Az eljárási szabályok rendezésére két lépcsőben került sor. Az átfogó szabályokat a Strukturális Alapok és a Kohéziós Alap felhasználásának általános eljárási szabályairól szóló 14/2004. (VIII. 13.) TNM-GKM-FMM-FVM-PM együttes rendelet tartalmazza. A részletes rendelkezések különbözö ágazati rendeletek alapján (pl.: 22/2004. (VI. 8.) FMM-OM együttes rendelet), de nem jogszabályi formában alakulnak ki. Ezeket a szabályokat ún. kézikönyvbe foglalják (az irányító hatóság, az operatív program végrehajtásának részletes eljárási szabályait tartalmazó mủködési kézikönyve), melyek jogszabályként viselkednek, ugyanis betartásuk mindenki számára kötelező. A kézikönyvet és módosításait - pl.: a HEFOP - esetén az irányító hatóság vezetöjének előterjesztése alapján foglal koztatáspolitikai és munkaügyi miniszter - az Oktatási Minisztériummal történő egyeztetés után - adja ki, és vonja vissza. Ez a tény kifejezetten a jogal kotás során alkalmazott módszerekre utal, noha a végeredmény mégsem egy miniszteri rendelet.

A jelzett kézikönyv mellett további kézikönyv is készülhet, amelyet - szintén a HEFOP esetén - az OM Alapkezelő a közoktatási, szakképzési és felsőoktatási intézkedések végrehajtására készít el. Az OM Alapkezelö belső müködési kézikönyvét az irányító hatóság vezetöje hagyja jóvá.

A jogi szabályozás mellőzése többek között kizárja a felsőbb szintủ (pl.. alkotmánybírósági) normakontrollt, nem garantálja a magyar és a közösségi jogrendszer céljainak, elveinek érvényesülését, változtatására megalkotója bármikor, bármilyen jogi felelősség nélkül, bármilyen hatásra lépést tehet. Jogállamban a társadalom (a potenciális kedvezményezettek) jelentős körének életviszonyait, általában a közpénzek elosztásának részletes feltételeit jogszabályok keretei között rendezik. Ezt követeli meg (az alkotmánybírósági gyakorlatban többször is érvényesített) jogbiztonság elve és a jogalkotásról szóló 1987. évi XI. törvény is. Jelen pillanatban Magyarországon ezeket a követelményeket úgy tünik kevéssé veszik figyelembe.

Az általános szabályokról szóló 14/2004. (VIII. 13.) TNM-GKM-FMM-FVM-PM együttes rendelet megalkotása Magyarországon dicséretes tény, mindazonáltal nem alkalmas a pártatlan, befolyástól mentes döntéshozatali mechanizmus garantálására.

A jogszabályban nem szerepelnek olyan - a fenti cél szolgálatában álló - elemek, amelyek a klasszikus eljárásjogok nélkülözhetetlen tényezöi közé sorolhatók.

Ilyennek tekinthető például a nyilvánosság elve, melyet a jelzett rendelet csupán a pályázati felhívások, a döntésrỏl szóló eredmények közzététele, segítségnyújtás (GYIK-FAQ) tekintetében tart érvényesítendőnek. Nem, illetöleg rendkívül szüken rendelkezik a jogszabály az irat betekintési jogról (csupán a döntést követöen lehet megtekinteni az emlékeztetöt, illetve az értékelő lapot), valamint a személyes jelenlét jogáról, melyek korlátozására a klasszikus eljárásjogok esetén csak a büntetőeljárás nyomozati szakában van lehetőség.

A nyilvánosság korlátozása csupán üzleti, szolgálati titkok védelmében, illetöleg a konkrét döntés meghozatalakor lehet indokolt, minden más esetben a titkolózás 
helyett a szêles körü tájékoztatást, vagy tájékozódás lehetöségét szükséges elönyben részesíteni.

Az eljárásban részvevök cselekményeire vonatkozó írásbeli dokumentálás követelménýe nem megfelelő mélységben szabályozott. Az emlékeztető helyett részletes, ha szükséges szó szerinti jegyzőkönyvezésre lenne szükség (hang-, videószalag rögzítés mellett), amely a - könyvvitel esetén már közösségi szinten ismert és szabályozott - nyomvonal követését biztosíthatná.

A benyújtott pályázatok elbírálása három részböl tevődik össze:

- értékelés,

- bírálat,

- döntés.

Az értékelést a gyakorlatban a közremúködö szervezetek végzik, melyre - mint döntés-elökészítỏ szakaszra - a vonatkozó szabályozás bizonyos partneri szervezetek korlátozott bevonását is biztosítja. A partneri közremüködés igénybevétele nem kötelező, szükségességéről a lebonyolító szervezet dönt. A lebonyolító (közremüködö) szervezet határozza meg, hogy kit tart érdekeltnek az adott projekt értékelésével kapcsolatosan. A szervezet által meghatározott körbe tartozó partnerek a szervezet által meghatározott határidőn ${ }^{4}$ belül véleményt nyilváníthatnak, vagy támogató nyilatkozatot adhatnak arra vonatkozóan, hogy milyen mértékben segíti elő a projekt az érintett pályázati felhívás céljait. A jogszabály szerint az értékelést végző a pályázat értékelése során úgy veszi figyelembe a társadalmi partnerek véleményét, hogy a prioritás és intézkedés céljai, továbbá a támogatást igénylök esélyegyenlösége ne sérüljenek.

A partnerek bevonására vonatkozó kötelezettség hiánya, a potenciális partnerek körének és az ésszerü határidő megjelölésének mellőzése, valamint vélemény figyelembe vételének kötelezettségét meghatározó rendkívül szük körü szabály nem feltétlenül áll összhangban a partnerség jelenlegi és a jövőbeni közösségi szabályozásával.

A következő két szakaszban (bírálat, döntés) kevéssé, illetőleg egyáltalán nem találhatók rendelkezések a partnerség elvének kívánatos biztosítására vonatkozóan.

A pályázatok elbírálásában kulcsfontosságú szerepet játszik a bíráló bizottság, melyet a regionális operatív program esetén döntés-elökészítö bizottságnak hívnak. A partnerség elvét jelen esetben legfeljebb az jelezheti, hogy a bizottság vezetỏjét és tagjait nem az irányító hatóság vezetöje nevezi ki. A tagokra vonatkozóan a jogszabály - a projekt célokhoz illeszkedő jogi és pénzügyi szakismeret követelményén túl - semmilyen további rendelkezést nem tartalmaz. A bizottság tagságára illetően (de lege ferenda) legalább két további követelmény fogalmazható meg. A tagoknak, illetőleg az egész szervezetnek alkalmasnak kell lennie arra, hogy a beérkezö - és várhatóan igen nagyszámú - pályázati anyagok értékelése megfelelő időn belül és magas szakmai színvonalon lezáruljon. Másrészt a bizottság tagságának összhangban kell lennie a partnerség elvével, ami a következő szereplök jelenlétét igényli:

- a politikai élet képviselöi,

- a közigazgatási szféra delegáltjai,

- a gazdasági szféra delegáltjai, 
Finta István: A jogi szabályozás szerepe a közösségi források felhasználásában.

Tér és Társadalom, 20. 2006. 2. 103-113. p.

- a szociális és egészségügyi szféra delegáltjai,

- az oktatási szféra delegáltjai,

- érdekképviseleti szervek,

- további civil szervezetek delegáltjai,

- a munkaadók és munkavállalók képviselöi.

A döntést az irányító hatóság vezetője, illetve az általa kijelölt személy hozza meg, aki vagy elfogadja a bíráló bizottság javaslatát, vagy pedig új értékelésre utasítja azt. A folyamat ezen szakaszában a partnerség már nem jelenik meg, igaz nem is tünik fontosnak, ha a megelöző szakaszokban az megfelelöképpen érvényesül. Ezt viszont a jogi szabályozás egyelöre nem garantálja.

Az értékeléssel, döntés-elökészítéssel kapcsolatosan szükséges felhívni a figyelmet azokra a megállapításokra, amelyek a közremüködő szervezetek és az irányító hatóságok munkájának egyfajta megítélésére nyújtanak lehetőséget. Az államigazgatási szervekre jellemzö életritmus és szemléletmód átitatja az egyes szervezetek, de különösen az irányító hatóságok apparátusának tevékenységét. Kétségtelen, hogy a hivatali keretek között müködő - jó értelemben vett - bürokratikus szervezetrendszer számos előnnyel rendelkezik, különösen a tipikus hatósági ügyintézés területén. A területfejlesztés viszont nem alapvetỏen hatósági feladat - sőt talán egyáltalán nem az - így a bürokratikus szemlélet előnyei sem feltétlenül kamatoztathatók. Ez egyúttal azt is jelentheti, hogy az államigazgatási szervezet elönyei a müködéshez nem feltétlenül illeszkedő feladattelepítés esetén visszájukra fordulhatnak. A gyakorlatban ez oly módon mutatkozik meg, hogy a pályázatok értékelésével foglalkozó dolgozók inkább feláldoznak egy jó, a célokhoz igazodó, de a kiírás betüjéhez 100\%-ban nem illeszkedő programot, (mely utóbbi ok többnyire a kiirás tökéletlenségében rejlik), mintsem, hogy elutasítsák a kevésbé jó, de a pályázati kiírásnak papírforma szerint tökéletesen megfelelö programot. Ez utóbbit azért fogadják el szívesebben, mert nem kívánnak olyan támadási felületet nyújtani, amiért esetleg később felelösséget kell vállalni. (Egy köztisztviselöt - a jelenlegi köztisztviselöi jogviszonyra vonatkozó törvény alapján - nehezebb akkor ,megbüntetni” ha nem tesz semmint, mint akkor, ha véletlenül hibázik.) A jelenlegi (tényleges) szervezeti forma és jogi szabályozás arra ösztönzi az alkalmazottakat, hogy a kockázat és a felelősségvállalás lehetőségét a minimálisra csökkentsék, akár a szervezet létrehozásához, müködéséhez füződő cél feláldozása árán is. (Az ilyen típusú csinovnyik szemlélet feltehetően a brüsszeli bürokrácia világától sem idegen.)

A vizsgált jogszabály elöírja az elutasító vagy csökkentett tartalmú támogatásról szóló döntés részletes indoklásának kötelezettségét, melynek természetesen semmi jelentősége nincs, ha az ellen jogorvoslati lehetőséggel nem lehet élni. Ezt pedig a rendelet semmilyen formában nem biztosítja. Mindez azt jelenti, hogy a döntéshozók a későbbi kontroll és felelősség teljes mellőzésével folytathatják tevékenységüket. A jogorvoslati lehetőség biztosításának egyik fontos célja az esetleges tévedések, megalapozatlan döntések káros következményeinek kiküszöbölése. Ennek hiányában csak az feltételezhetö, hogy az arra jogosult mindig és minden körülmények között csak tökéletes döntéseket hozhat, így aztán a jogorvoslat biztosítása teljesen szükségtelen. 
A demokratikus berendezkedésü államok joggyakorlatában ez a típusú felfogás ismeretlen, viszont közel áll az egyházjogból ismert pápai csalhatatlanság dogmájához.

A Strukturális Alapok forrásaihoz kötödően egyetlen egy jogszabály jelentett kivételt, amely biztosította - a teljesen evidensnek tünő - jogorvoslat lehetőségét. Ez a jogszabály a mezőgazdasági és vidékfejlesztési támogatásokhoz és egyéb intézkedésekhez kapcsolódó eljárás egyes kérdéseiröl és az ezzel összefüggő törvénymódosításokról szóló 2003. évi LXXIII. törvény. A jogszabály ugyan kivette a pályázati eljárás rendezését az államigazgatási eljárás általános szabályai alól azzal az indokkal, hogy az elbírálás összetett folyamata nem teszi lehetövé a törvény által elöírt rövid elintézési határidők betartását. Ugyanakkor a Mezőgazdasági és Vidékfejlesztési Hivatal elutasító döntésével szemben a pályázó írásban az MVH elnökéhez címzett kifogást terjeszthetett elö a döntés kézhezvételétöl számított tizenöt napon belül. Az MVH elnöke a kifogást a benyújtástól számított harminc napon belül bírálta el. Az MVH elnökének döntése ellen további jogorvoslatnak helye nem volt, de a pályázó elött nyitva állt a bírósági út igénybevételének lehetősége ${ }^{5}$.

A Strukturális Alapok forrásainak elosztásában részvevő szervezetek múködésére vonatkozó jogi szabályozás hiányosságai már a gyakorlatban is mutatkoznak. Ezt, illetőleg az egyes irányító hatóságok szabadságának korlátlanságát és felelősségének hiányát érzékelteti egy közelmúltban megtörtént eset. Az egyik operatív programra benyújtott pályázatot az irányító hatóság - a közremúködő szervezetek javaslatának megfelelően - támogatandónak értékelte. Erröl a pályázat benyújtóját értesítették, de a szerződés megkötésére egyelőre nem került sor. Ezt követően az irányító hatóság változtatott álláspontján, és tartalék listára helyezte a projektet. Nemrégiben a pályázó immár hivatalos értesítést kapott az irányító hatóságtól, hogy pályázatát elutasították.

A jogi szabályozás hiányosságai szoros összefüggésben álnak az irányító hatóság általában véve az egyes szervezetek - státuszának tisztázatlanságával. A jelenleg hatályos 1260/99. EK rendelet rendkívül széles lehetőséget biztosít az irányító hatóság státuszának meghatározására. Azt viszont nem teszi lehetővé, hogy a státusz kérdésében történő döntésre egyáltalán ne kerüljön sor. Jelen pillanatban Magyarországon nem lehet tudni, hogy az irányító hatóságok valójában milyen szervezetek, státuszuk megfoghatatlan, fantomként tevékenykednek a magyar közigazgatás szervezetében. Az Európai Unió Strukturális Alapjaiból és Kohéziós Alapjából származó támogatások hazai felhasználásáért felelös intézményekröl 1/2004. (I. 5.) szóló kormányrendelet csupán azt rögzíti, hogy az operatív program irányító hatóság az adott operatív program megvalósítására, és az operatív program jogszabályoknak megfelelő adminisztratív, pénzügyi és szakmai irányítására kijelölt szervezeti egység. Az operatív program irányító hatóság vezetỏje - eltérő vezetöi megbízatás hiányában - a miniszter által kinevezett helyettes államtitkári juttatású személy. Az operatív program irányító hatóság feladatainak ellátásáért az adott operatív program felügyeletét ellátó miniszter felelös.

Köztudott, hogy az irányító hatóságokat az egyes minisztériumok keretein belül szervezeték meg. Ha megvizsgáljuk az irányító hatóságok és a vele kapcsolatban álló szervezetek közötti - többnyire jogilag szabályozott - viszonyt, akkor arra a 
következtetésre juthatunk, hogy az irányító hatóság az államigazgatási szervezetrendszer tipikus szereplöje. Ennek jogszabályi rögzítését viszont gondosan megkerülték, melynek számos okai közül csupán az egyik lehet az, hogy államigazgatási szervként történő definiálásuk esetén az eljárási rendjükre alkalmazni kell az államigazgatási eljárásról, illetőleg a közigazgatási hatósági eljárás és szolgáltatás általános szabályiról szóló törvényt.

A jelenlegi helyzetben, ha egy ROP közremüködő szervezet hozza meg - esetleg téves, megalapozatlan - döntését, az ellen semmilyen jogorvoslati joggal nem lehet élni. Ezek a közremúködö szervezetek ugyanis Kht-k, az-az nem közigazgatási szervek. Az alkotmány - és a kapcsolódó jogszabályok - csak a közigazgatási szervek határozata elleni jogorvoslati lehetőséget biztosítják. Egy Kht. döntése ellen szóljon az közcélról és akár milliárdos közpénzröl - nem lehet jogorvoslatot igénybe venni. Az ilyen lehetséges eset a jogállamban gondołkodó jogalkotót és jogalkalmazót egyaránt felkészületlenül éri, és teljesen védtelen, valamint kiszolgáltatott helyzetet teremt az érintett fél számára is.

Más a helyzet, ha a döntést az Irányító Hatóság hozza. Az intézményrendszer vizsgálata során bemutatott érvekböl egyértelmüen következik, hogy az irányító hatóságok központi közigazgatási szervnek minösülnek. Ugyanakkor Alkotmányunk lehetővé teszi a közigazgatási határozatok elleni jogorvoslatot, így egy irányító hatóság (pl.: elutasító) döntése ellen irányuló jogorvoslati kérelem esetén az illetékes bíróság minden bizonnyal megállapítaná hatáskörét, és eljárna az ügyben. Igaz ugyan, hogy a jogorvoslatra - alkotmánysértő módon - ez ideig nem született szabályozás, és az is igaz, hogy olyan kétharmados törvény sincs, amely a jogorvoslati jog korlátozásáról rendelkezne.

A jelenlegi, nem megfelelő szintủ, mélységü és minöségủ jogszabályi környezet fenntartása addig és azoknak állhat érdekében, amíg jelentős pénzekröl történik döntés, és ezek útját bizonyos érdekek, csoportosulások befolyásolni kívánják. A megfelelö jogi szabályozás nem csodaszer, de mindenképpen megnehezíti a közösségi céloknak nem a leginkább megfelelö, a pártatlanság követelményét mellózỏ döntések megszületését.

A Strukturális Alapok forrásainak elosztásához kötődő pályázati rendszer jogi szabályozása napjainkban alapvetö hiányosságokat mutat. Egyáltalán nem, vagy csak részlegesen biztosítja a Strukturális Alapok múködését évtizedek óta és vélhetően évtizedek múlva is meghatározó alapelvek érvényesưlését. A szabályozás ezen túlmenően figyelmen kívül hagyja a magyar alkotmányos jogrendszer alapértékeit és az egyes eljárásjogok által kimunkált jogintézményeket.

A fentiek tükrében elengedhetetlennek tünik a jelenlegi szabályozás felülvizsgálata és átalakítása, melynek persze további szükségszerü feltétele a vonatkozó döntéshozatali mechanizmus jogállami normákhoz és értékekhez történő közelítése, pontosabban ennek felismerése, megkövetelése és - szükség esetén - kikényszerítése. 


\section{Jegyzetek}

'Harmadik kohéziós jelentés: 164. o,, „Vezetői összefoglalō” 30. o. Európai Közösségek 2004.

${ }^{2}$ A pályázati kiírásban a hátrányos helyzetủ területek, csoportok támogatása néha elérendỏ célként fogalmazódik meg, azonban a gyakorlati értékelés során e tényezöknek még sincs meghatározó jelentôsége, melyet leginkább a nyertes projektek listája fémjelez. A támogatások jelentös részét az amúgy is kedvezőbb helyzetủ települések nyerik el. (Lásd, pl.: Az „INTEGRÁLT HELYI FEJLESZTÉSI AKCIÓK ÖSZTÖNZÉSE" c. 2002/000-315.01.06, Phare pályázat, KUUZDELEM A MUNKA VILÁGÁBÓL TÖRTÉNỐ KIREKESZTŐDÉS ELLEN Helyi kezdeményezések támogatása a tartós munkanélkülick és rendszeres szociális segélyben részesillő́k munkaeröpiaci integrációja érdekében HU2002/000-315.01. $0^{4}$. stb.)

Pályázati felhívás a falufejlesztés és -felújitás, a vidék tárgyi és szellemi ơrökségének védelme és megőrzése támogatására.

4 A 2004-2006. közötti programozási idöszakra vonatkozó tervezés során a különbözố partnereknek néhány hetes, de gyakran néhány napos határidöt adtak az egyes operativ programok véleményezésére. $\mathrm{Ez}$ a partneri együttmüködést teljesen formálissá tette, hiszen az idő rövidsége miatt érdemi közremüködésre nem nyílt lehetőség.

5

A törvény akkori indok lása szerint: „Mivel a pályázati cljárás nem tartozik az államigazgatási eljárás hatálya alá, ezért a pályázatok esetében az Áe. által elốrt jogorvoslatok sem alkalmazhatóak, de az ùgyfél részére abból a célból, hogy alkotmányos jogai ne sérüljenek, mindenképpen biztosítani kell a Hivatal elutasító dơntésével szemben jogorvoslati lehetöséget. Pályâzatok esetében a kifogás jelenti a jogorvoslati lehetöséget a pályázó számára. A kifogás elöterjesztésére az általános szabályoknak megfelelöen 15 napos határidő áll az ìgyfél rendelkezésére, melyet írásban, az MVH elnökéhez címezve kell benyúitani, és azt a benyújlástól számított 30 napon belül el kell bírálni. Az MVH elnökének döntése ellen további jogorvoslatnak nincs helye, az ügyfél ezt követôen az ügyben már csak bírósághoz fordulhat."

\section{Irodalom}

Forman B. (2000) Regionális politika az Európai Unióban. Váti Kht.

Forman B. (2003) Az Európai Unió strukturális és elöcsatlakozási alapjai. INTERPRESS.

Gergó Zs.-Szilágyi I. (szerk.) (2002) Gazdasági-szocialis kohézió és strukturális politika az Európai Unióban: elmélet és gyakorlat. VE Társadalomtudományok és Európai Tanulmányok Tanszék, Veszprém.

Hetényi G.-Stelbaczky T.-Zalai Cs. (2001) Az Európai Unió támogatási politikája. Press Publica, Budapest. $128 \mathrm{o}$.

Horváth Gy. (1998) Európai regionális politika. Dialóg Campus Kiadó, Budapest-Pécs.

Horváth Gy. (2001) Az Európai Unió strukturális és kohéziós politikájának szabályozása. MTA RKK. Pécs. 233 o.

Pálné Kovács I. (2001) Regionális politika és közigazgatcis. Dialóg Campus Kiadó, Budapest-Pécs.

Pálné Kovács I. (2003) Regionális önkormányzatok és a regionális politika (területfejlesztés) irányítása http://www.idea.gov.hu/portal/server.pt?space=CommunityPage \& cached=true\&parentname=CommunityPage \&parentid=0\&in_hi_userid=709\&control=SetCommunity\&CommunityID=274\&PageID=0

Radnóczy Zs. (2004) Támogatások az Európai Unióban. A közösségi támogatások jogalapja, az összeegyeztethetôség és a jogvédelem kérdése. Akadémiai Kiadó, Budapest. 